\title{
PENGARUH MODEL PEMBELAJARAN KOOPERATIF TIPE JIGSAW TERHADAP HASIL BELAJAR MATEMATIKA SISWA KELAS VIII SMP NEGERI 6 METRO
}

\author{
Ummi Rosyidah \\ Program Studi Pendidikan Matematika, Universitas Nahdlatul Ulama Lampung \\ Email: ummirosyium09@gmail.com
}

\begin{abstract}
Abstrak
Salah satu cara peningkatan kualitas pembelajaran yaitu dengan peningkatan relevansi model mengajar. Model mengajar dikatakan relevan jika dalam prosesnya mampu mengantarkan siswa mencapai tujuan pendidikan. Oleh karena itu, diperlukan upaya untuk dapat menyampaikan materi pelajaran kepada siswa dengan model yang relevan dengan kebutuhan siswa. Salah satu alternatif, yaitu dengan menggunakan model pembelajaran Jigsaw. Tujuan penelitian ini adalah untuk mengetahui pengaruh penggunaan model pembelajaran kooperatif tipe Jigsaw terhadap hasil belajar matematika siswa kelas VIII di SMP Negeri 6 Metro. Penelitian ini menggunakan desain penelitian Quasi Experimental Design. Bentuk desain quasi eksperimen yang digunakan dalam penelitian ini adalah Nonequivalent Control Group Design. Data yang diperoleh dianalisis secara statistik deskriptif. Subjek penelitian ini adalah siswa kelas VIII SMP Negeri 6 Metro yang berjumlah 28 siswa. Hasil penelitian menunjukkan bahwa data yang dianalisis dengan menggunakan uji- $t$ pada taraf signifikan $5 \%$ yaitu hasil $t_{\text {hitung }}>t_{\text {tabel }}$ yaitu 1,870 $>1,701$. Berdasarkan hasil penelitian dapat disimpulkan bahwa penggunaan model pembelajaran kooperatif tipe Jigsaw memberikan pengaruh terhadap hasil belajar matematika siswa kelas VIII di SMP Negeri 6 Metro.
\end{abstract}

Kata Kunci: Model Pembelajaran, Koperatif tipe Jigsaw, Hasil Belajar.

\section{Pendahuluan}

Perkembangan dan kemajuan suatu bangsa sangat dipengaruhi oleh mutu pendidikan. Pendidikan pada dasarnya adalah suatu proses untuk membantu manusia dalam mengembangkan dirinya, sehingga mampu menghadapi segala perubahan dan permasalahan yang dihadapi. Indonesia sangat membutuhkan sumbangan yang optimal dari warga negara Indonesia. Hal tersebut menjadi suatu cita-cita pendidikan untuk pemerintah.

Untuk meningkatkan mutu pendidikan, bangsa Indonesia mencanangkan program wajib belajar selama sembilan tahun. Dalam program tersebut diharapkan seluruh anggota masyarakat mendapatkan kesempatan untuk memperoleh pendidikan dimana kecerdasan dan kemampuannya dapat dikembangkan secara optimal melalui proses belajar. Belajar mengandung dua pokok pengertian yaitu proses dan hasil belajar. Proses belajar di sini dapat dimaknai sebagai suatu kegiatan dan usaha untuk mencapai perubahan tingkah laku, sedangkan perubahan tingkah laku tersebut merupakan hasil belajar.

Dalam meningkatkan mutu pendidikan perlu ditunjang adanya pembaharuan di bidang pendidikan. Salah satu caranya adalah melalui peningkatan kualitas pembelajaran yaitu dengan pembaharuan pendekatan atau peningkatan relevansi model mengajar. Model mengajar dikatakan relevan jika dalam prosesnya mampu mengantarkan siswa mencapai tujuan pendidikan melalui pembelajaran namun dalam kenyataannya masih banyak guru yang mengajar secara monoton yaitu hanya menggunakan satu metode saja, misalnya metode konvensional. Padahal belum tentu setiap pokok bahasan suatu materi pelajaran cocok dan efektif diajarkan dengan metode konvensional.

Tugas seorang guru tidaklah mudah, harus mampu membimbing dan mengarahkan anak didiknya agar dapat belajar dan memperoleh hasil belajar yang diharapkan. Serta dalam 
penggunaan model pembelajaran tersebut tidak asal pilih karena disesuaikan dengan keadaan siswa. Masing-masing model pembelajaran juga mempunyai kelebihan dan kekurangan. Tujuan pemilihan model mengajar ini adalah untuk mengefektifkan proses belajar mengajar guna meningkatkan daya serap siswa terhadap materi pelajaran tersebut, karena dari kenyataan yang ditemui, bahwa apa yang dicapai masih jauh dari apa yang diharapkan. Alternatif penggunaan model pembelajaran yang melibatkan siswa aktif dalam proses pembelajaran adalah model pembelajaran kooperatif. Model pembelajaran kooperatif merupakan model pembelajaran yang melibatkan siswa berinteraksi dan bekerja sama dengan teman. Zakaria dan Iksan (2007) menyatakan bahwa "belajar kelompok/kerjasama dipercaya paling efektif karena murid dengan aktif terlibat dalam berbagi ide dan pekerjaan untuk melengkapi tugas akademis". McMaster dan Fuchs (2002) menyatakan bahwa "pada penelitian yang dilakukan pada tahun 1990-2000 menunjukkan bahwa pembelajaran kooperatif sangat berpengaruh terhadap prestasi akademik siswa yang mempunyai kesulitan belajar".

Akan tetapi, pada kenyataannya, hasil belajar siswa pada mata pelajaran matematika masih sangat rendah. Hal ini dapat kita lihat dari perilaku siswa yang selalu beranggapan bahwa matematika adalah pelajaran yang sangat sulit untuk dipelajari. Dalam proses pembelajaran, siswa kurang memiliki semangat, merasa ngantuk dan jenuh, serta hasil belajar masih sangat kurang. Hal ini disebabkan oleh beberapa faktor, di antaranya: pembelajaran tersebut sangat membosankan, banyak materi yang tidak dimengerti, sehingga suasana tidak kondusif, siswa pun tidak aktif dalam proses pembelajaran dan membuat hasil belajar tidak mencapai standar yang diharapkan dan ditentukan.

Dengan latar belakang tersebut di atas, peneliti mencoba untuk menciptakan hal yang baru, maka penulis menggunakan judul "Pengaruh Penggunaan Model Pembelajaran Kooperatif Tipe Jigsaw terhadap Hasil Belajar Matematika Siswa Kelas VIII di SMP Negeri 6 Metro".

Berdasarkan latar belakang di atas, maka rumusan masalah penelitian ini adalah "Apakah ada pengaruh penggunaan model pembelajaran kooperatif tipe Jigsaw terhadap hasil belajar matematika siswa kelas VIII di SMP Negeri 6 Metro". Tujuan yang diharapkan dari dilaksanakannya penelitian ini adalah untuk mengetahui pengaruh penggunaan model pembelajaran kooperatif tipe Jigsaw terhadap hasil belajar matematika siswa kelas VIII di SMP Negeri 6 Metro.

\section{Tinjauan Pustaka}

Joyce dan Weil (dalam Rusman, 2010), model pembelajaran disusun berdasarkan berbagai prinsip-prinsip pembelajaran, teori-teori psikologis, sosiologis, analisis sistem atau teori-teori lain yang mendukung. Model pembelajaran kooperatif sendiri disusun berdasarkan prinsip/faham konstruktivisme. Joyce (dalam Suprijono, 2009) menyatakan bahwa fungsi model adalah each model guides us as we design instruction to help students achieve various objectives. Melalui model pembelajaran guru dapat membantu siswa mendapatkan informasi, ide, keterampilan, cara berpikir, dan mengekspresikan ide.

Slavin (2005) mengungkapkan bahwa sangat banyak dari model-model teoritis yang dapat menjelaskan keunggulan pembelajaran kooperatif. Teori tersebut terbagi menjadi dua kategori utama, motivasi dan kognitif. Teori motivasi dalam pembelajaran kooperatif menekankan pada derajat perubahan tujuan kooperatif mengubah insetif bagi siswa untuk melakukan tugas-tugas akademik, teori kognitif menekankan pada pengaruh dari kerja sama itu sendiri.

Model pembelajaran kooperatif dikembangkan untuk mencapai setidak-tidaknya tiga tujuan pembelajaran penting, yaitu hasil belajar akademik, penerimaan terhadap keragaman dan 
pengembangan keterampilan sosial (Rusman, 2010). Di samping model pembelajaran kooperatif dikembangkan untuk mencapai hasil belajar kompetensi akademik, model pembelajaran kooperatif juga efektif mengembangkan kompetensi sosial siswa. Beberapa ahli berpendapat bahwa model ini unggul dalam membantu siswa memahami konsep-konsep yang sulit. Para pengembang model ini telah menunjukkan bahwa model struktur penghargaan kooperatif telah dapat meningkatkan penilaian siswa pada belajar akademik dan yang berhubungan dengan prestasi belajar.

Bern dan Erickson (dalam Komalasari, 2010) menyatakan bahwa cooperative learning (pembelajaran kooperatif) merupakan strategi pembelajaran yang mengorganisir pembelajaran dengan menggunakan kelompok belajar kecil dimana siswa bekerja sama untuk mencapai tujuan pembelajaran.

Rusman (2013) menyatakan bahwa model pembelajaran kooperatif adalah bentuk kegiatan pembelajaran dengan cara siswa belajar dan bekerja dalam kelompok kecil secara kolaboratif yang terdiri dari empat sampai enam orang dengan struktur kelompok yang heterogen.

Lie (dalam Rusman, 2013) menyatakan bahwa pengertian model pembelajaran kooperatif tipe Jigsaw adalah model belajar kooperatif dengan cara siswa belajar dalam kelompok kecil yang terdiri dari 4 - 6 siswa secara heterogen, memberikan kesempatan siswa dapat bekerja sama, saling ketergantungan positif di antara siswa dan siswa mampu bertanggung jawab secara mandiri.

(Sutawidjaja, dkk, 2011) menyatakan bahwa: Jigsaw pertama-tama dikembangkan oleh Ellior Aronson (1978). Teknik ini kemudian diadaptasi menjadi Jigsaw. Dalam Jigsaw siswa bekerja dalam kelompok yang terdiri atas 4 orang dengan kemampuan yang bervariasi seperti dalam STAD atau TGT. Siswa diberi tugas membaca artikel, buku singkat atau bahan bacaan lainnya, biasanya dalam ilmu pengetahuan sosial, biografi, atau bahan dalam bentuk lainnya. Setiap anggota kelompok secara acak dipilih untuk menjadi seorang ahli dalam bagian tertentu dari bahan bacaan yang diberi oleh guru. Setelah membaca bagian yang menjadi tugasnya, para ahli berkumpul dengan anggota kelompok lain yang bacaannya sama berdiskusi tentang isi bahan bacaan itu dalam suatu kelompok ahli. Setelah selesai, mereka dianggap sudah menjadi ahli dalam bagian itu, kemudian kembali ke kelompok semula dengan tugas menjelaskan bahan yang dikuasai tersebut kepada anggota kelompoknya. Kemudian mereka secara individual mengambil quiz atau assessment lainnya tentang seluruh bahan bacaan tersebut.

Slavin (2008) pada penggunaan model pembelajaran kooperatif tipe jigsaw perlu adanya persiapan sebagai berikut:

1. Materi

Sebelum pelajaran dimulai, guru memilih satu atau dua bab, cerita, atau unit-unit lainnya kemudian buat sebuah lembar ahli untuk tiap unit dan membuat kuis, tes berupa esai, atau bentuk penilaian lainnya untuk tiap unit. Untuk membantu mengarahkan diskusi dalam kelompok ahli gunakan skema diskusi.

2. Membagi siswa ke dalam kelompok awal

Membagi siswa ke dalam kelompok heterogen yang terdiri dari empat sampai lima anggota.

3. Membagi siswa ke dalam kelompok ahli

Siswa dapat ditempatkan dalam kelompok ahli secara acak atau dengan memutuskan sendiri siswa mana yang akan masuk ke kelompok ahli yang mana.

4. Penentuan skor pertama 
Skor awal mewakili skor rata-rata siswa pada kuis sebelumnya atau jika belum pernah diadakan kuis maka dapat menggunakan hasil nilai terakhir siswa dari tahun sebelumnya.

Kegiatan-kegiatan pembelajaran dalam Jigsaw menurut Slavin (2008) terdiri dari:

1. Membaca

Para siswa menerima topik ahli dan membaca materi yang diminta untuk menemukan informasi.

2. Diskusi kelompok ahli

Para siswa dengan keahlian yang sama bertemu untuk mendiskusikannya dalam kelompok-kelompok ahli.

3. Laporan tim

Para ahli kembali ke dalam kelompok mereka masing-masing untuk mengajari topiktopik mereka kepada teman satu kelompoknya.

4. Tes

Para siswa mengerjakan kuis individual yang mencakup semua topik.

5. Rekognisi tim

Setelah diadakan kuis, sesegera mungkin menghitung skor kemajuan individual dan skor tim. Kemudian tim yang mendapat skor tertinggi diberi penghargaan.

Gambar 1. Posisi Siswa dalam Model Jigsaw

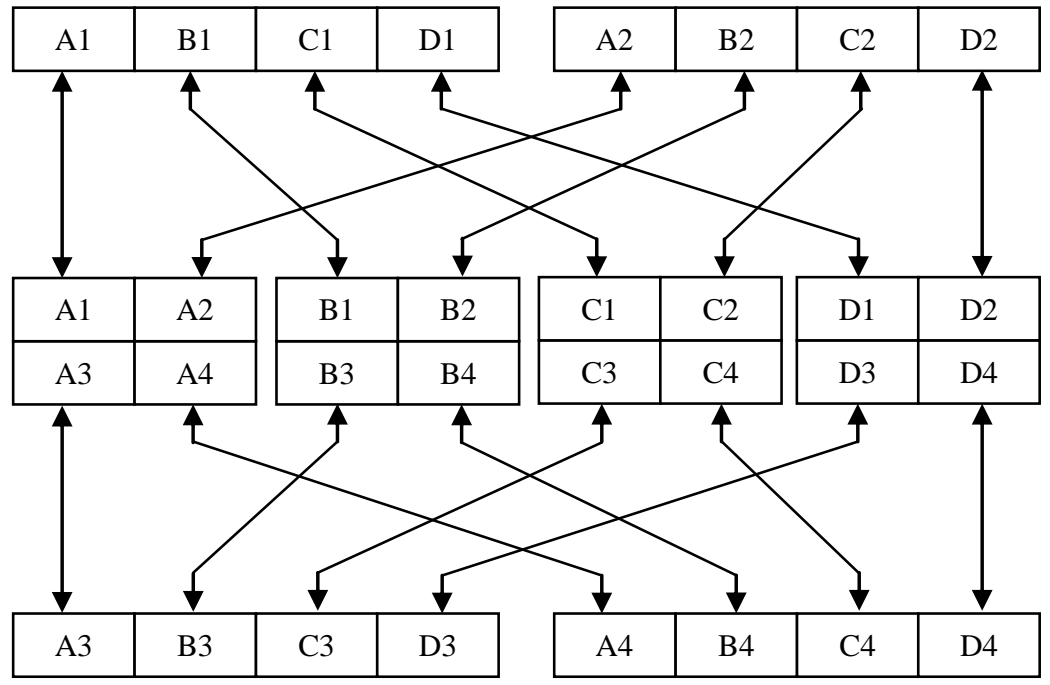

Sumber: (Adaptasi Komalasari, 2010)

Langkah - langkah pembelajaran dengan model kooperatif tipe Jigsaw pada penelitian ini adalah:

Kegiatan Pendahuluan

1. Guru mengkondisikan siswa dan menyampaikan tujuan pembelajaran kepada siswa.

2. Guru mengarahkan kepada siswa model pembelajaran yang akan digunakan.

3. Kelas dibagi menjadi beberapa kelompok yang anggotanya terdiri dari 4-6 siswa secara heterogen dan disebut sebagai kelompok asal.

Kegiatan Inti

1. Setiap siswa pada masing-masing kelompok asal diberi satu bagian materi yang akan dibahas.

2. Anggota kelompok yang mendapatkan bagian materi yang sama berkumpul menjadi satu kelompok dan disebut dengan kelompok ahli yang anggotanya terdiri dari 4-6 siswa.

3. Siswa pada kelompok ahli mendiskusikan bagian materi yang menjadi tanggungjawabnya. 
4. Siswa yang berada di kelompok ahli kembali ke kelompok asal untuk mengajar anggota lain mengenai materi yang telah dipelajari dalam kelompok ahli.

Kegiatan Penutup

1. Setelah diskusi dalam kelompok asal, semua siswa dievaluasi secara individual mengenai semua materi yang telah dipelajari.

2. Setelah dilakukan evaluasi, diadakan pemberian skor dan penghargaan kelompok.

Isjoni (2011) kelebihan dan kekurangan pembelajaran kooperatif tipe Jigsaw adalah:

1. Dalam kelas kooperatif siswa dapat berinteraksi denga teman sebayanya dan juga dengan gurunya sebagai pembimbing.

2. Motivasi teman sebaya dapat digunakan secara efktif untuk meningkatkan, baik pembelajaran kognitif siswa maupun pertumbuhan efektif siswa.

3. Menumbuhkan tanggung jawab siswa.

4. Mendorong siswa aktif dan saling membantu dalam menguasai materi pelajaran.

5. Untuk mengoptimalkan manfaat belajar kelompok.

Kekurangan pembelajaran kooperatif tipe Jigsaw di antaranya:

1. Siswa dengan bebas memilih kuis dan diberikan nilai individu.

2. Secara efektif di tiap level siswa telah mendapatkan keterampilan akademis dari pemahaman.

Piaget dan Vigotsky (dalam Karwono \& Mularsih, 2010) menyatakan bahwa "dalam belajar, siswa membangun sendiri pengetahunnya. Karena proses belajar itu datang dari dalam diri individu bukan datang dari luar individu". Dimyati dan Mudijono (2006) menyatakan bahwa, hasil belajar merupakan hasil dari suatu interaksi tindak belajar dan tindak mengajar. Dari sisi guru, tindak mengajar diakhiri dengan proses evaluasi dan hasil belajar. Dari sisi siswa, hasil belajar merupakan berakhirnya penggal dan puncak.

Karwono dan Mularsih (2012) menyatakan terdapat empat komponen pokok dalam merumuskan indikator hasil belajar yaitu:

1. Penentuan subjek belajar untuk menunjukkan sasaran belajar.

2. Kemampuan atau kompetensi yang dapat diukur atau yang dapat ditampilkan melalui performance siswa.

3. Keadaan dan situasi dimana siswa dapat mendemonstrasikan contoh soal.

4. Standar kualitas dan kuantitas hasil belajar.

Sobur (2003) mengemukakan secara garis besar, faktor-faktor yang mempengaruhi belajar anak atau individu dapat dibagi dalam dua bagian, yaitu:

1. Faktor endogen atau disebut juga faktor internal, yakni semua faktor yang berada dalam diri individu.

2. Faktor eksogen atau sering disebut juga faktor eksternal, yakni semua faktor yang berada di luar diri individu, misalnya orang tua atau kondisi lingkungan di sekitar individu.

Wasliman (dalam Susanto, 2013) ada dua macam faktor yang mempengaruhi proses belajar, yaitu:

1. Faktor internal, yakni faktor yang bersumber dari dalam diri siswa yang mempengaruhi kemampuan belajarnya. Faktor internal ini meliputi: kecerdasan, minat dan perhatian, motivasi belajar, serta kondisi fisik dan kesehatan.

2. Faktor eksternal, yakni faktor yang berasal dari luar diri siswa yang mempengaruhi hasil bejalar yaitu keluarga, sekolah dan masyarakat.

Faktor-faktor yang mempengaruhi hasil belajar menurut Munadi (dalam Rusman, 2013) antara lain meliputi: 


\section{Faktor Internal}

a. Faktor fisiologis. Secara umum kondisi fisioligis, seperti kesehatan yang prima, tidak dalam keadaan lelah dan capek, tidak dalam keadaan cacat jasmani dan sebgainya. Hal tersebut dapat mempengaruhi siswa dalam menerima materi pelajaran.

b. Faktor Psikologis. Setiap individu dalam hal ini siswa pada dasarnya memiliki kondisi psikologis yang berbeda-beda, tentunya hal ini turut mempengaruhi hasil belajarnya. Beberapa faktor psikologis meliputi intelegensi (IQ), perhatian, minat,bakat, motif, motivasi, kognitif, dan daya nalar siswa.

2. Faktor Eksternal

a. Faktor Lingkungan. Faktor lingkungan dapat mempengaruhi hasil belajar. Faktor lingkungan ini meliputi lingkungan fisik dan lingkungan sosial. Lingkungan alam misal suhu, kelembaban dan lain-lain. Belajar pada tengah hari di ruangan yang kurang akan sirkulasi udara akan sangat berpengaruh dan akan sangat berbeda pada pembelajaran pada pagi hari yang kondisinya masih segar dan dengan ruangan yang cukup untuk bernapas lega.

b. Faktor Instrumental. Faktor instrumental adalah faktor yang keberadaannya dirancang sesuai dengan hasil belajar yang diharapkan. Faktor-faktor ini diharapkan dapat berfungsi sebagai sarana untuk tercapainya tujuan-tujuan belajar yang direncanakan. Faktor-faktor instrumental ini berupa kurikulum, saran dan guru.

\section{Metodologi Penelitian}

Dalam penelitian ini terdapat satu variabel bebas dan satu variabel terikat yaitu model pembelajaran kooperatif tipe Jigsaw sebagai variabel bebas dan hasil belajar matematika sebagai variabel terikat. Penelitian ini merupakan jenis penelitian eksperimen menggunakan pendekatan deskriptif kuantitatif. Desain penelitian yang digunakan dalam penelitian ini adalah Quasi Experimental Design. Bentuk desain quasi eksperimen yang digunakan dalam penelitian ini adalah Nonequivalent Control Group Design. Desain ini hampir sama dengan Pretest-Posttest Control Group Design, hanya pada desain ini kelompok eksperimen dan kelompok kontrol tidak dipilih secara random (Sugiyono, 2011). Populasi dalam penelitian ini adalah siswa kelas VIII SMP Negeri 6 Metro. Sedangkan populasinya berjumlah 28 siswa untuk masing-masing kelas.

Instrumen yang digunakan dalam penelitian ini adalah:

1. Validasi, yaitu suatu ukuran yang menunjukkan tingkat-tingkat kevalidan atau kesahihan sesuatu instrumen. Suatu instrumen yang valid atau sahih mempunyai validitas tinggi. Sebuah instrumen dikatakan valid apabila mampu mengukur apa yang diinginkan.

2. Indeks kesukaran item: butir-butir item tes hasil belajar dapat dinyatakan sebagai butirbutir item yang baik, apabila butir-butir item tersebut tidak terlalu sukar dan tidak pula terlalu mudah.

3. Daya pembeda item: daya pembeda item adalah kemampuan suatu butir item tes hasil belajar untuk dapat membedakan (mendiskriminasi) antara testee yang berkemampuan tinggi, dengan testee yang berkemampuan rendah, demikian rupa sehingga sebagian besar testee yang memiliki kemampuan tinggi untuk menjawab butir item tersebut lebih banyak yang menjawab betul, sementara testee yang kemampuannya rendah untuk menjawab butir item tersebut sebagian besar tidak dapat menjawab item dengan betul.

4. Reliabilitas: reliabilitas menyatakan sampai dimana keajegan ketepatan dari hasil pengukuran. Suatu tes dapat dikatakan mempunyai taraf kepercayaan yang tinggi jika tes tersebut dapat memberikan hasil yang tetap.

Untuk mengumpulkan data digunakan metode tes, dan metode dokumentasi. Metode tes digunakan untuk mengumpulkan data mengenai hasil belajar matematika siswa, sedangkan metode dokumentasi digunakan untuk mengetahui keadaan hasil belajar di sekolah yang diambil dari nilai matematika. Adapun teknik analisis data yang digunakan untuk menguji 
hipotesis dalam penelitian ini adalah pengujian hipotesis menggunakan rumus $\mathrm{T}_{\text {tes }}$ maka populasinya harus berdistribusi normal dan varians kedua kelompok yang diuji adalah sama, untuk itu dilakukan uji normalitas dan homogenitas.

\section{Hasil dan Pembahasan}

Data hasil belajar dalam penelitian ini meliputi dua macam yaitu data yang diperoleh dari hasil pretest dan hasil postest. Data hasil pretest diberikan sebelum siswa mendapat perlakuan (treatment) menggunakan model pembelajaran kooperatif tipe Jigsaw dan data hasil postest diberikan setelah siswa mendapatkan perlakuan (treatment) menggunakan model pembelajaran kooperatif tipe Jigsaw untuk mengetahui hasil belajar matematika. Adapun deskripsi data yang telah didapat yaitu sebagai berikut:

\section{Uji Normalitas}

a. Data hasil pretest diperoleh $\bar{X}=64,071$ dan $s=6,079$ maka nilai $L=\mid F\left(z_{i}\right)-$ $S\left(z_{i}\right)$ | yang paling besar yaitu 0,1414 . Sedangkan dari tabel normalitas Lilliefors pada taraf signifikansi $5 \%$ dengan ukuran sampel $n=28$ adalah 0,1641. Oleh karena, $L_{\text {hit }}<L_{\text {tabel }}$ maka $H_{0}$ diterima yang artinya distribusi frekuensi data yang diuji adalah normal.

b. Data hasil postest diperoleh $\bar{X}=80,429$ dan $s=8,513$ maka nilai $L=\left|F\left(z_{i}\right)-S\left(z_{i}\right)\right|$ yang paling besar yaitu 0,1300 . Sedangkan dari tabel normalitas Lilliefors pada taraf signifikansi 5\% dengan ukuran sampel $n=28$ adalah 0,1641. Oleh karena, $L_{h i t}<$ $L_{\text {tabel }}$ maka $H_{0}$ diterima yang artinya distribusi frekuensi data yang diuji adalah normal. Sehingga dapat disimpulkan berdistribusi normal.

\section{Uji Homogenitas}

Dari perhitungan yang telah dilakukan, diperoleh variansi terbesar adalah 121,8462 dan variansi terkecil 90,6667, maka:

$$
F_{\text {hit }}=\frac{\text { Varians } \text { Terbesar }}{\text { Varians Terkecil }}=\frac{36,958}{49,296}=0,7497
$$

Diperoleh $F_{\text {hit }}=0,7497$ pada taraf signifikansi 5\% dengan $F_{\text {tabel }}=1,9048$. Oleh karena $F_{\text {hit }}<F_{\text {tabel }}$ maka keputusan ujinya adalah $H_{0}$ diterima. Berdasarkan keputusan uji tersebut, maka dapat disimpulkan bahwa data masing-masing sampel berasal dari populasi dengan variansi yang homogen.

\section{Uji Hipotesis}

Pengujian hipotesis ini dilakukan setelah dilakukan uji normalitas dan uji homogenitas. maka dilanjutkan pengujian hipotesis untuk mengetahui apakah ada pengaruh $\mathrm{X}$ (model pembelajaran kooperatif tipe Jigsaw) terhadap Y (hasil belajar) maka data dianalisis dengan menggunakan rumus regresi linier sederhana maka data yang telah dikumpulkan dianalisis. Berdasarkan perhitungan maka diketahui bahwa persamaan regresi linier sederhana $\hat{Y}=$ $50,6522+0,5826 X$. Kemudian untuk menguji apakah ada pengaruh penggunaan model pembelajaran kooperatif tipe Jigsaw terhadap hasil belajar matematika siswa kelas VIII SMP Negeri 6 Metro, maka dibuktikan dengan menggunakan rumus menggunakan uji statistik $t$. Dengan analisis perhitungan nilai $t_{\text {hitung }}$ dan $t_{\text {tabel }}$ tersebut diketahui bahwa $t_{\text {hitung }}>t_{\text {tabel }}$ yaitu $1,870>1,701$. Dengan demikian hipotesis berbunyi: Ada pengaruh yang positif dalam penggunaan model pembelajaran kooperatif tipe Jigsaw terhadap hasil belajar matematika siswa kelas VIII SMP Negeri 6 Metro.

Penggunaan model pembelajaran kooperatif tipe Jigsaw dalam penelitian ini menggunakan LKS yang diberikan kepada siswa. Sebelum penelitian siswa diarahkan. Penelitian pertama kali peneliti menyampaikan materi dengan menggunakan model pembelajaran kooperatif tipe Jigsaw. Dalam pembelajaran kooperatif tipe Jigsaw, peneliti mengkondisikan siswa dan 
menyampaikan tujuan pembelajaran kepada siswa. Peneliti mengarahkan kepada siswa model pembelajaran yang akan digunakan. Kelas dibagi menjadi beberapa kelompok yang anggotanya terdiri dari 4-6 siswa secara heterogen dan disebut sebagai kelompok asal.

Pada pertemuan selanjutnya, setiap siswa pada masing-masing kelompok asal diberi satu bagian materi yang akan dibahas.Anggota kelompok yang mendapatkan bagian materi yang sama berkumpul menjadi satu kelompok dan disebut dengan kelompok ahli yang anggotanya terdiri dari 4-6 siswa. Siswa pada kelompok ahli mendiskusikan bagian materi yang menjadi tanggungjawabnya. Siswa yang berada di kelompok ahli kembali ke kelompok asal untuk mengajar anggota lain mengenai materi yang telah dipelajari dalam kelompok ahli. Setelah diskusi dalam kelompok asal, semua siswa dievaluasi secara individual mengenai semua materi yang telah dipelajari. Akhir penelitian, peneliti memberikan post-test untuk mengetahui hasil belajar matematika dari siswa. Setelah dilakukan evaluasi, diadakan pemberian skor dan penghargaan kelompok.

Berdasarkan kegiatan-kegiatan tersebut, hasil belajar siswa dapat meningkat. Hal tersebut juga dapat dilihat dari uji hipotesis yaitu $t_{\text {hitung }}=1,870$ dan $t_{t a b} 1,701$ pada taraf signifikansi $5 \%$ menghasilkan $t_{\text {hitung }}>t_{t a b}$. Dengan demikian.,dapat disimpulkan bahwa ada pengaruh positif antar model pembelajaran kooperatif tipe Jigsaw terhadap hasil belajar matematika pada siswa kelas VIII SMP Negeri 6 Metro. Nilai-nilai dari hasil belajar matematika dari pre-test dan post-test, setelah diberikan perlakuan menggunakan model pembelajaran kooperatif tipe Jigsaw dapat dilihat pada tabel berikut:

Tabel 1. Persentase Hasil Belajar Matematika Siswa Kelas VIII SMP Negeri 6 Metro

\begin{tabular}{ccccccc}
\hline \multirow{2}{*}{ No } & \multirow{2}{*}{ Nilai } & Kriteria & \multicolumn{2}{c}{ Pre-Test } & \multicolumn{2}{c}{ Post-test } \\
\cline { 3 - 7 } & & Jumlah & Persentase & Jumlah & Siswa & Persentase \\
& & Siswa & & & 25 & 92,86 \\
\hline 1 & $\geq 70$ & Tuntas & 7 & 75 & 2 & 7,14 \\
2 & $<70$ & Belum Tuntas & 21 & 100 & 28 & 100 \\
\hline & & 28 & Jumlah &
\end{tabular}

Berdasarkan tabel di atas, dapat diketahui pada pre-test, bahwa siswa yang mencapai tuntas belajar hanya $25 \%$ atau 7 siswa, sedangkan siswa yang belum mencapai tuntas belajar adalah 75\% atau 21 siswa. Dengan demikian, dapat di temukan bahwa jumlah siswa yang belum tuntas belajar atau belum mencapai standar ketuntasan yang telah ditetapkan masih banyak yaitu $71,43 \%$ atau 20 siswa dari total keseluruhan 28 siswa.

Tabel di atas dapat menunjukkan bahwa pada post-test setelah siswa mendapatkan perlakuan menggunakan model pembelajaran kooperatif tipe Jigsaw yang mencapai tuntas belajar menjadi 92,86\% atau 26 siswa, sedangkan yang belum mencapai tuntas belajar 7,14\% atau 2 siswa dari keseluruhan 28 siswa.

Setelah siswa mendapatkan perlakuan menggunakan model pembelajaran kooperatif tipe Jigsaw mengalami peningkatan dalam hasil belajar yang dapat dilihat dari hasil pre-test dan hasil post-test yaitu siswa yang mencapai kriteria ketuntasan minimal (KKM) 70 yaitu pada pre-test siswa yang tuntas sebanyak $25 \%$ atau 7 siswa, sedangkan yang belum tuntas sebanyak $75 \%$ atau 21 siswa. Pada post-test siswa yang tuntas sebanyak 92,86\% atau 26 siswa, sedangkan yang belum tuntas sebanyak $7,14 \%$ atau 2 siswa. Hasil pre-test total nilai yaitu 1794 sedangkan untuk hasil post-test total nilai yaitu 2252. Peningktan dilihat dari nilai awal dan nilai akhir yaitu sebesar 458. Dan hal tersebut dapat dilihat dari hasil pre-test diperoleh rata-rata nilai sebesar 64,07 dan untuk hasil post-test diperoleh nilai rata-rata sebesar 80,43. 
Hasil penelitian ini sesuai dengan hasil penelitian yang dilakukan Putra (2014) menunjukkan bahwa ada pengaruh penerapan model pembelajaran kooperatif tipe Jigsaw terhadap hasil belajar. Sejalan dengan penelitian yang telah dilakukan Isjoni (2011) pembelajaran kooperatif dapat meningkatkan keinginan kelas, prestasi yang dipertahankan dan prestasi aktual. Prestasi aktual seperti yang disebutkan sebelumnya, pengukuran prestasi aktual ini mengindikasikan bahwa peserta menunjukan secara signifikan pada ujian dengan sistem belajar kooperatif dibanding dengan belajar pasif.

Peningkatan nilai yang signifikan disebabkan karena adanya treatment yaitu model pembelajaran kooperatif Jigsaw yang lebih merangsang siswa untuk berpikir aktif dan mengharuskan siswa untuk membaca agar mampu memperoleh poin yang tinggi ketika treatment. Perlakuan yang diberikan peneliti adalah model pembelajaran Jigsaw pada mata pelajaran matematika. Dalam pembelajaran dengan model pembelajaran Jigsaw siswa diajak untuk lebih bekerja sama terhadap temanya dan menumbuhkan sikap percaya diri. Pembelajaran ini bertujuan untuk mengetahui pengaruh model pembelajaran Jigsaw terhadap hasil belajar siswa.

Dari hasil analisis deskriptif dapat diketahui bahwa pemberian perlakuan model pembelajaran kooperatif Jigsaw memberikan dampak positif pada nilai siswa. Hal itu ditunjukkan dari adanya peningkatan nilai yang signifikan pada kelas yang diberi perlakuan. Kelas yang diberi perlakuan memiliki kesiapan dan persiapan yang lebih matang sebelum mengikuti pembelajaran. Dengan adanya perlakuan dalam pembelajaran akan melatih anak untuk untuk selalu berpikir aktif dan mendorong anak untuk melakukan persiapan sebelum pembelajaran dilakukan.

\section{Simpulan dan Saran \\ Simpulan}

Berdasarkan hasil penelitian dan analsis data yang telah diuraikan, maka dapat ditarik kesimpulan bahwa tes hasil belajar diperoleh rata-rata pretest 64,07 dan untuk nilai rata-rata post-test sebesar 80,43. Dari hasil tersebut membuktikan bahwa rata-rata hasil belajar siswa yang diajarkan dengan menggunakan model pembelajaran kooperatif tipe Jigsaw lebih tinggi sebelum siswa diajarkan dengan menggunakan model pembelajaran kooperatif tipe Jigsaw.

Hasil perhitungan hipotesis post-test dengan melalui uji- $t$ pada taraf signifikansi 0,05 yaitu didapat hasil $t_{\text {hitung }}>t_{\text {tab }}(1,879>1,701)$. Dari hasil tersebut dapat diambil kesimpulan bahwa uji hipotesis menolak hipotesis nol $\left(\mathrm{H}_{0}\right)$ dan menerima hipotesis alternatif $\left(\mathrm{H}_{1}\right)$. Lebih lanjut, hasil perhitungan ini membuktikan bahwa pembelajaran dengan menggunakan model pembelajaran kooperatif tipe Jigsaw memberikan pengaruh yang positif terhadap hasil belajar.

\section{Saran}

Berdasarkan hasil penelitian menggunakan model pembelajaran kooperatif tipe Jigsaw ini, ada beberapa saran yang perlu disampaikan sebagai berikut:

a. Sekolah seharusnya menggunakan model pembelajaran kooperatif tipe Jigsaw untuk merangsang siswa belajar secara aktif dan menarik, sehingga berdampak terhadap peningkatan hasil belajar siswa.

b. Guru hendaknya dapat menggunakan model kooperatif tipe Jigsaw sebagai alternatif dalam proses belajar mengajar, karena model kooperatif tipe Jigsaw berpengaruh positif dalam meningkatkan hasil belajar siswa.

c. Siswa hendaknya ikut berperan aktif dalam setiap proses pembelajaran di kelas, lebih bertanggung jawab terhadap tugasnya, dan pemahaman secara kognitif dan psikomotor, 
melalui teman yang mempunyai kemampuan lebih baik akan menjadi salah satu faktor peningkatan hasil belajar.

\section{Daftar Pustaka}

Dimyati dan Mudijono. (2006). Belajar dan Pembelajaran. Jakarta: Rineka Cipta.

Isjoni. (2011). Cooperative Learning Efektivitas Pembelajaran Kelompok. Bandung: Alfabeta.

Karwono, \& Mularsih, H. (2010). Belajar dan Pembelajaran Serta Pemanfaatan Sumber Belajar. Jakarta: Cerdas Jaya.

Komalasari, Kokom. (2010). Pembelajaran Kontekstual. Bandung: Refika Aditama.

McMaster, K.N. and Fuchs, D. (2002). Cooperative Learning on the Academic Achievement of Students with Learning Disabilities: an Update of Tateyama- Sniezek's Review. Learning Disabilities Research \& Practice Journal, Vol. 17 No. 2. 107-117.

Putra, D. S. (2014). Penerapan Model Pembelajaran Kooperatif Tipe Jigsaw terhadap Hasil Belajar Chest Pass pada Permainan Bolabasket (Studi pada siswa Kelas VII SMP Negeri 5 Sidoarjo). Jurnal Pendidikan Olahraga dan Kesehatan, Vol. 02 No. 03 Tahun 2014. 526 - 531. http://ejournal.unesa.ac.id/article/13076/68/article.pdf

Rusman. (2010). Model-Model Pembelajaran Mengembangkan Profesionalisme Guru. Jakarta: PT Rajagrafindo Persada.

Rusman. (2013). Model-Model Pembelajaran: Mengembangkan Profesionalisme Guru. Edisi ke-2. Jakarta: PT. RajaGrafindo Persada.

Slavin, R. E. (2005). Cooperative Learning Teori, Riset dan Praktik. Bandung: Nusa Media.

Slavin, R. E. (2008). Cooperative Learning Teori, Riset dan Praktik. Bandung: Nusa Media.

Sobur, Alex. (2003). Psikologi Umum. Bandung: Pustaka Setia.

Sugiyono. (2011). Metode Penelitian Kuantitatif Kualitatif dan R\&D. Bandung: Alfabeta.

Suprijono, Agus. (2010). Cooperative Learning Teori dan Aplikasi PAIKEM. Yogyakarta: pustaka belajar.

Susanto, Ahmad. (2013). Teori Belajar dan Pembelajaran di Sekolah Dasar. Jakarta: Kencana Prenada Media Group.

Sutawidjaja, A., dkk. (2011). Pembelajaran Matematika. Jakarta: Universitas Terbuka.

Zakaria, E. and Iksan, Z. (2007). Promoting Cooperative Learning in Science and Mathematics Education: A Malaysian Perspective. Eurasia Journal of Mathematics, Science \& Technology Education, Vol. 3 No. 1 Tahun 2007. 35-39. 